論文

\title{
高温におけるクリープ, 疲労条件下の表面を裂伝ぱ
}

\author{
小寺沢良一* 中 村 健 二** 藤 田和 孝***
}

\section{Propagation of Surface Cracks under Creep and Fatigue \\ Conditions at Elevated Temperatures}

by

\author{
Ryoichi KoterazAWA \\ (Institute of Engineering Mechanics, University of Tsukuba, Ibaraki) \\ Kenji NAKAmURA \\ (Kawasaki Heavy Industries, Ltd., Akashi) \\ and Kazutaka FujiTA \\ (Ube Technical College, Ube)
}

Propagation of surface cracks under creep-fatigue conditions at elevated temperatures was studied with a SUS 304 steel and a $21 / 4 \mathrm{Cr}-1 \mathrm{Mo}$ steel. The shape of cracks was semi-circular in most cases and the propagation rate was the same in the surface direction as in the depth direction. The creep crack propagation rates of surface cracks under constant stresses agreed with those of through-thickness cracks in the $\dot{j}$ diagram. Microscopic fracture morphology was predominantly intergranular creep type. In the cases of repeated stresses, similarly to the case of through-thickness crack previously reported, crack propagation was controlled by $\Delta K$ in the low stress region and by $\dot{J}$ in the high stress region, microscopic fracture morphology being fatigue striation type and creep dimple type, respectively. This is true, however, only for large cracks and, in the case of small cracks, crack propagation was controlled by $\dot{J}$ even in the low stress region, microscopic fracture morphology being still fatigue striation type.

キー・ワード: フラクトグラフィ, クリープ, 疲労, き裂, 破壊力学

(Received Aug. 25, 1982)

\section{1 緒言}

高温に打いてクリープが起る条件下のき裂伝ぱの研 究は, 最近かなり多く行われているが，その大部分は 貫通き裂に関するものであって，非貫通き裂関する 研究は注とんどない，非貫通き裂の一形態で㐫る表面 き裂は実際の破壊に多くみられ, その挙動を明らかに することは実用上重要な意味をもっている.

筆者らは，寸法の異る貫通き裂試験片を用いて，ク リープ条件下のき裂伝ぱを支配する破壊力学因子を明 らかにするための一連の研究を実施し，クリープが著 しい条件下では修正 $\mathrm{J}$ 積分 $\dot{J} か ゙$ 支配力学因子であるこ とを示し，これに関連する破買機構をフラクトグラフ 、により検討してきているが，ここではその一環とし て表面き裂について実験を行った結果を報告する.

\footnotetext{
$\dagger$ 原稿受理 昭和57年 8 月25日

* 正会員 筑波大学構造工学系 茨城県新治郡桜村

** 川崎重工業(株) 明石市川崎町

*** 宇部工業高等専門学校 宇部市常盤台
}

\section{2 試 験 方 法}

供試材は SUS 304 鋼（溶体化処理材）を主とし, 一部, 特飞延性の低い材料の例として $21 / 4 \mathrm{Cr}-1 \mathrm{Mo}$ 鋼 （水焼入材）を用いた。試験片は板状試験片の中央片 側に小孔をあけたもので，幅 $12 \sim 13.3 \mathrm{~mm}$ ，厚さ 5 〜 $6 \mathrm{~mm}$ ，小孔直径 $1 \mathrm{~mm}$, 深さ $1.4 \sim 1.5 \mathrm{~mm}$ （大きい き裂) と幅 9 12 mm，厚さ $5 \sim 6 \mathrm{~mm}$ ，小孔直径 0.2 $\mathrm{mm}$, 深さ $0.2 \mathrm{~mm}$ (微小き裂) の 2 種を使用した. 試験温度は 304 鋼については $650^{\circ} \mathrm{C}, \mathrm{Cr}-\mathrm{Mo}$ 鋼につ

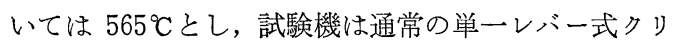
ープ試験機である. 繰返し応力試験の場合は, ジャッ キで重錘を上げ下るしすることにより負荷している. き裂長さは, 304 鋼の一定応力試験では試験片表面 （遊尺付望遠顕微鏡による）打よび破面上で， Cr-Mo 鋼の試験および繰返し応力試験では破面上で測定した. またすべての試験に扎いて試験片のき裂中央開口変

*1き裂の開口が少く，試験片表面て测定团難. 
位を遊尺付望遠顕微鏡により測定し，修正 J 積分の評 価に用いた。

\section{3 一定応力下のき裂伝ぱ}

（1）大きいき裂 304 鋼の破面写真例を Fig. 1 に 示す。 小孔付試験片に絽返し応力により予き裂を入れ， クリープき裂伝ぱ試験後, 再び繰返し応力により破断 させている。破面形状け忯济半田形で (Fig. 1 (a)),

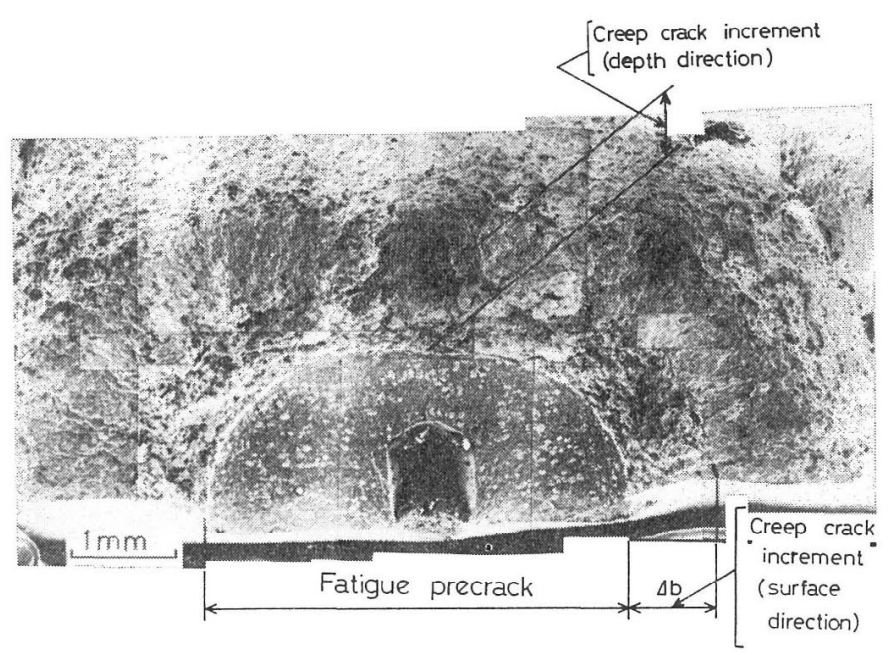

(a) Low magnification.

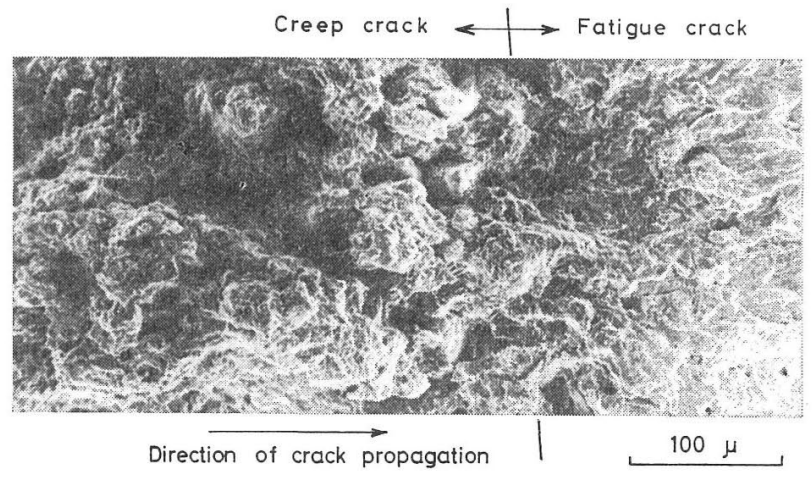

(b) High magnification.

Fig. 1. Fracture surface of a specimen tested under a constant stress (large crack, 304 steel).

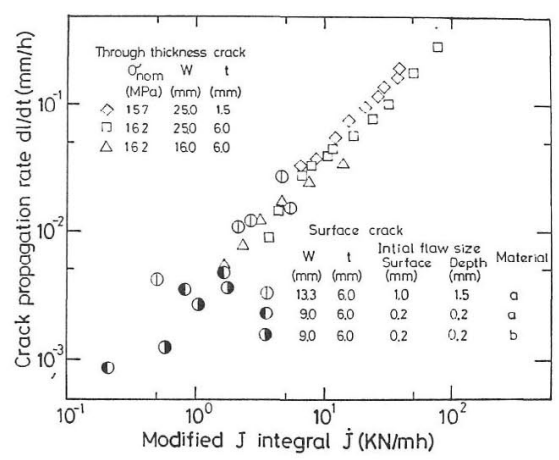

Fig. 2. $\dot{j}-d l / d t$ diagram (304 steel).
表面方向と深さ方向のき裂伝ぱ量はほぼ等しい。この ことから, 円周切欠さ丸棒試験片と同様の軸対称問題 とみなし, $\dot{J}=\sigma_{\text {net }} \dot{V}(\dot{V}:$ き裂中央開口速度) により $\dot{J}$ を求めた。得られた $\dot{J}$ と単位負荷時間あたりのき裂 伝ぱ速度 $d l / d t$ の関係を Fig. 2 飞示す (D印). 角印 で示した貫通き裂の結果とほぼ一致して和りこの場

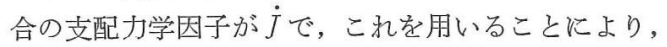
表面クリープき裂の伝ぱ速度学貫通ク リープき裂の伝ぱ速度と関係づけ得る ことを示している. 破面の微視的様相 は，貫通き裂と同様，粒界クリープ破 壊である (Fig. 1 (b)).

$\mathrm{Cr}-\mathrm{Mo}$ 鋼の破面写真例を Fig. 3 に 示す。試験片表面付近でき裂伝ぱの遅 れが著しいが，この部分觉除くと 304 鋼と同様，ほぼ半円形にき裂が伝ぱし ている. 表面付近の遅れを考慮して, Fig. 4 に模型的に示したように面積平 均をとってき裂伝ぱ速度を求めた。こ れを 304鋼の場合と同様にして得た に対して図示すると Fig.5 のよう になる。この場合も, 丸印で示した表 面き裂の結果は角印の賁通き裂の結果 のばらつきの範囲に入って物り, 低延 性材のこの例でるjが支配力学因子之 みて差支党ないことを示している。な 特，試験片表面付近に和けるき裂伝ぱ の遲れは，この材料の貫通き裂の伝ぱ にみられるトンネル化現象と関連して いるものと考它机るが，先の理由は 明らかでない。微視的破面様相は粒界 クリーブ破壊である(Fig.3)。

（2）微小き裂 304 鋼の微小さ裂 試験の破面例を Fig.6, Fig.7 に示 す. Fig. 6 は応力の低い場合，Fig.7 は応力の高い場合の例である．応力の 低い場合には, き裂前縁にかなりの凹円は㐫るが，全 体的には大きいき裂の場合と同様潘ぼ半円状である (Fig.6 (a)). 応力が高い場合には，き裂は表面方向に 著しく長い(Fig.7(a))。試験片表面では, Fig.6(b), Fig. 7 (b)にみられるように, 主き裂以外に多くの微小き裂 が発生して和り，応力が高い場合にはこれが主き裂と 合体して表面方向に長くなった様子がらかがわれる (Fig.7 (a)). 乙か乙，大きいき裂と同様に求めたjと 表面方向のき裂伝ぱ速度との関係は，Fig. 2 の半黒丸 の上らに大きいき裂の結果の延長線上にあり，微小き

*2 微視組織の影響と思われる. 


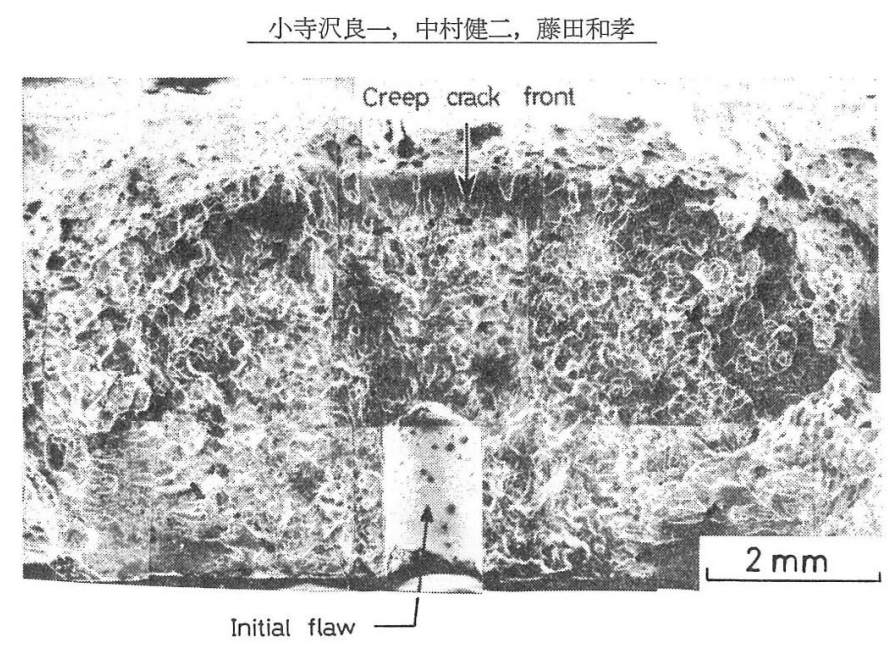

Fig. 3. Fracture surface of a specimen tested under a constant stress (large crack, 2-1/4Cr-1Mo steel).

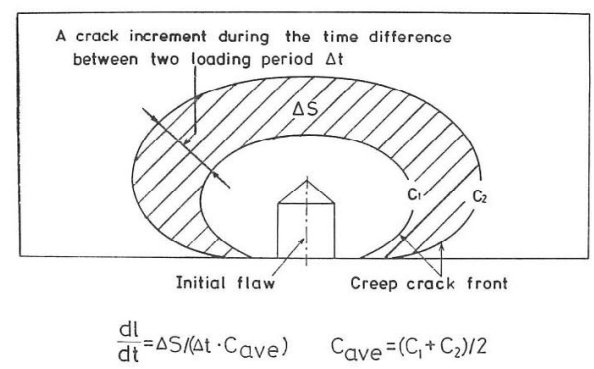

Fig. 4. A schematic illustration of a surface crack of the $2-1 / 4 \mathrm{Cr}-1 \mathrm{M}$ o steel.

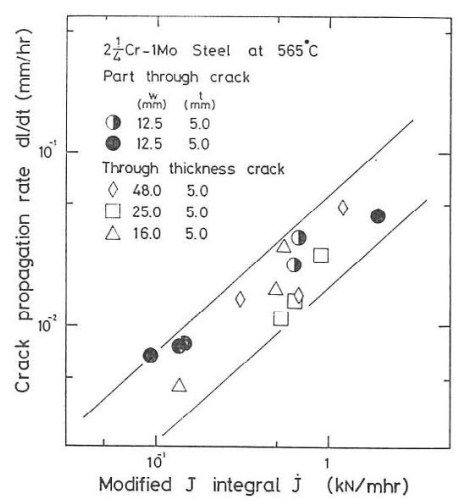

Fig. 5. $\dot{j}-d l / d t$ diagram $(2-1 / 4 \mathrm{Cr}-1 \mathrm{Mo}$ steel).

裂についても方が支配因子とみて差支觉ないことを示 している・な括，この結果は大谷らによる 316 鋼の微 小き裂に関する結果とほぼ一致している，微視的破面 様相は, 図に文られるよらに, 低応力, 高応力いずれ も粒界クリープ破壞である。

\section{4 繰返し応力下のき裂伝ぱ}

（1）大きいき裂 304鋼の破面写真例を Fig.8 そ 示与. 繰返乙応力は応力比 $R=0.05$, 繰返乙速度 $2 \mathrm{cpm}$ の矩形波片振引張りで, 試験中に下限応力と繰返し速 度を変党て $(R=0.5$, 速度 $4 \mathrm{cpm})$ ビーチ・マークを

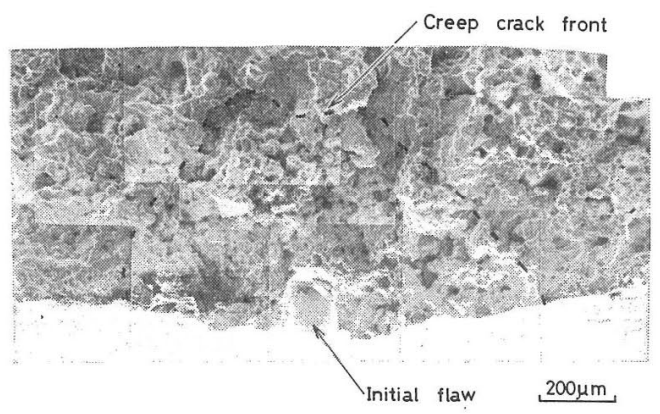

(a) Fracture surface.

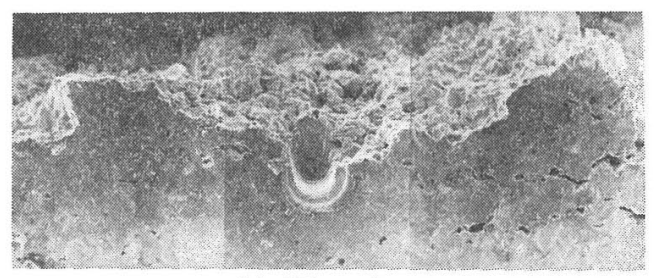

(b) Side surface.

Fig. 6. A specimen fractured under a constant stress (small crack, 304 steel, low stress $\left.\sigma_{\text {net }}=191 \mathrm{MPa}\right)$.

\section{入れた。き裂形状はこの場合もほぼ半円である。}

き裂伝ぱ速度 $d a / d n$ を $\Delta K$ で整理した結果をFig.9 に, 単位高応力負荷時間当りのき裂伝ぱ速度 $d a / d t$ を 修正 $\mathrm{J}$ 積分 $\dot{J}=\sigma_{\text {net }} \dot{V}$ ( $\dot{V}$ : 単位高応力負荷時間当り のさ裂開口速度) に対して図示した結果を Fig. 10 に 示す. Fig. 9 に执いて, 表面き裂の伝ぱ速度 (○印) は, 同一試験条件の貫通き裂の結果の $\Delta K$ 支配域を 示す実線に低伝ぱ速度域で収束し，この領域で $\Delta K$ が支配才学因子であることを示して和り，Fig.10に 扣いては，これと逆に高伝ぱ速度域に㧊いて静クリー プき裂伝ぱ速度を示与帯域（の，の，(1印）に一致 し, この領域で方が支配力学因子であることを示して いる.一方, 微視的破面様相は, Fig. 9, Fig. 10 に矢 


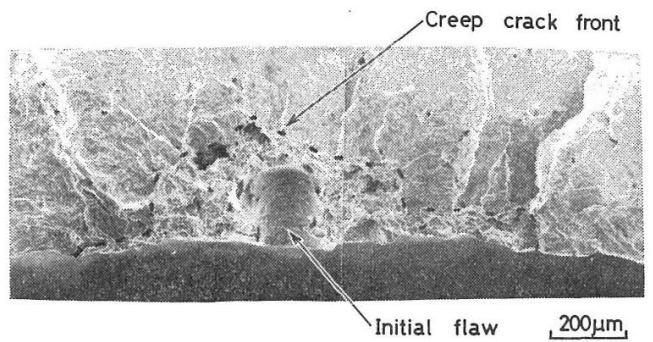

(a) Fracture surface.

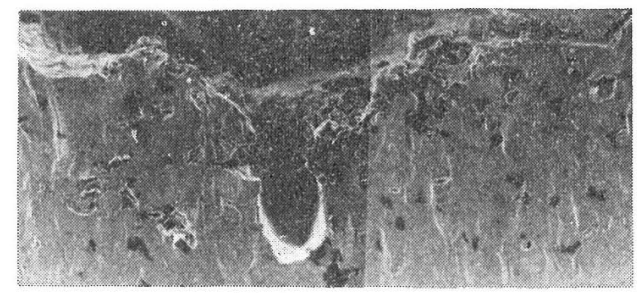

(b) Side surface.

Fig. 7. A specimen fractured under a constant stress (small crack, 304 steel, high stress $\left.\sigma_{\text {net }}=260 \mathrm{MPa}\right)$.

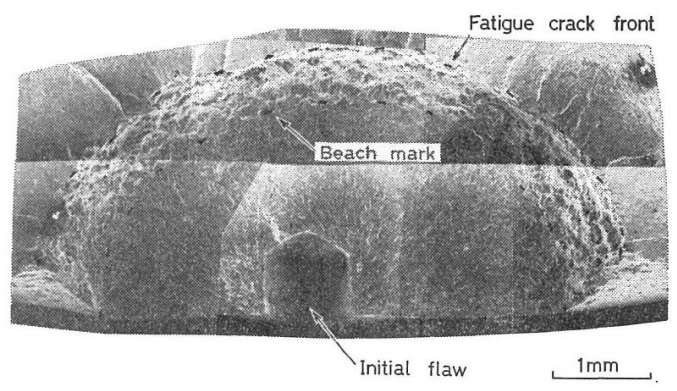

Fig. 8. Fracture surface of a specimen tested under repeated stress (large crack, 304 steel).

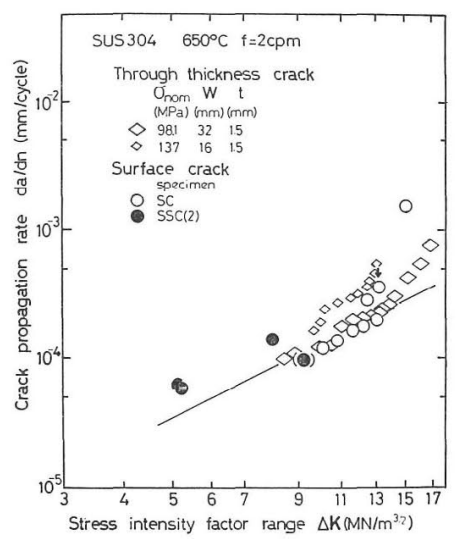

Fig. 9. $\Delta K-d a / d n$ diagram (304 steel).

印で示したき裂伝ぱ速度より低伝ぱ速度側ではストラ イエーション状模様が支配的で疲労破壞であることを 示して扔り，高伝ぱ速度側ではディンプルが支配的で クリープ破壞であることを示している，また，矢印の

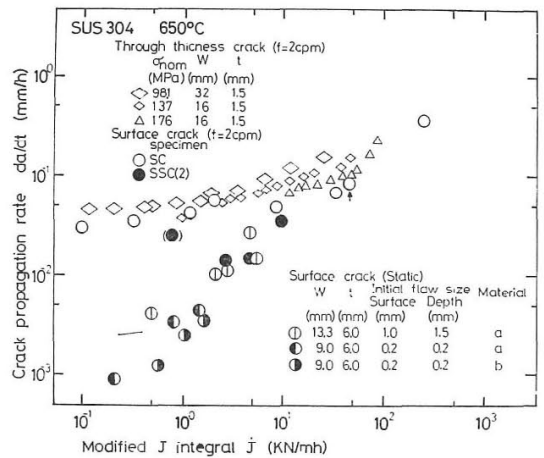

Fig. 10. $\dot{j}$-da/ct diagram (repeated stress, 304 steel).

点は，Fig. 10 に括いて実験結果 (○印) が静クリー プき裂伝ぱ試験の結果と傾きが一致しはじめる点に対 応している.これらの表面き裂伝ぱ挙動は, 既報の貫 通き裂の伝ぱ挙動と同様であり，クリープが起る条件 下の繰返乙応力下の表面き裂伝ぱが貫通き裂の伝ぱと 同様に扱党ることる示している.

（2）微小き裂 304 鋼の破面写真例を Fig.11 に 示す．試験方法は前項と同様である。この場合も，き 裂前縁形状は滦ぼ半円である (Fig. 11 (a))。さ裂伝ぱ 速度 $d a / d n$ を $\Delta K$ で整理 した結果を Fig. 9 に示す (○印). 微小き裂の結果は他の結果が収束した伝ぱ速 度より更に低い伝ぱ速度の領域にあるが，実線で示し た $\Delta K$ 支配線と一致せず，これより若干高いき裂伝ぱ 速度をもっている. 微視的破面様相はストライエーシ ヨン状模様が支配的で (Fig.11 (b)), 前項の大きいき

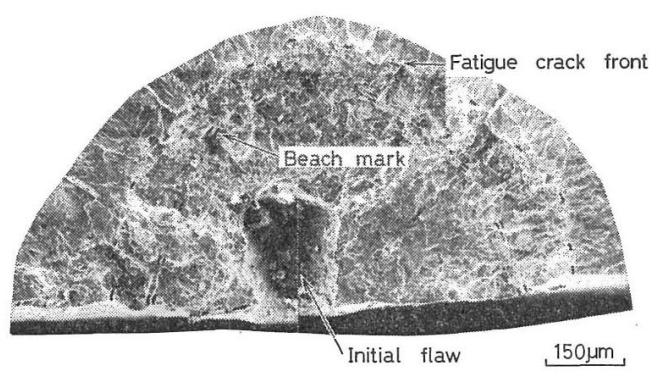

(a) Low magnification.

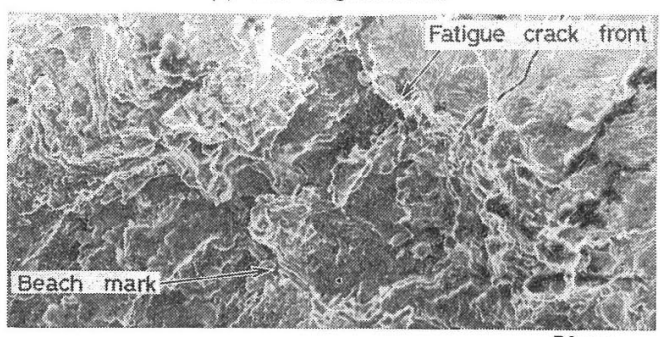

$50 \mu \mathrm{m}$

(b) High magnification.

Fig. 11. Fracture surface of a specimen tested under repeated stress (small crack, 304 steel). 


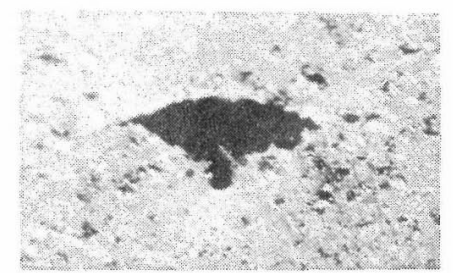

(a) $\dot{j}$-controlled (small crack).

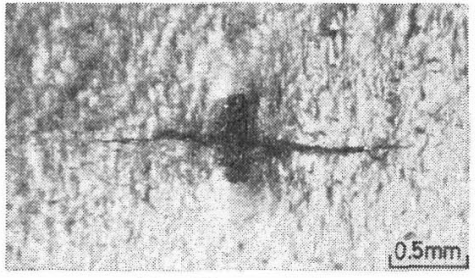

(b) $\Delta K$-controlled.

Fig. 12. Crack opening in repeated stress tests (304 steel).

裂の $\Delta K$ 支配域之变らない，一方，単位高応力負荷時 間当りのき裂伝ぱ速度 $d a j d t を \dot{J} て ゙$ 整理した結果(Fig. 10 印）は，伝ぱ速度が低いにもかかわらず，大きい き裂と異り静クリープき裂の結果（，，印）と 一致している.こ机はき裂が短いため小規模降伏条件

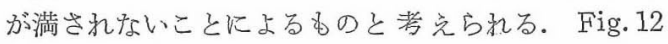
に, 上記の $\dot{J}$ に支配されている敗小さ裂の開口状態 (Fig. 12 (a)）を $\Delta K$ 亿支配されているき裂の開口状熊 (Fig. 12 (b)）と比較した例を示与. $\Delta K$ 支配のき裂の 先端が閉じているのに対して，广支配のき裂は著しく 開口していてクリープ変形が大きいことを示して拈り， 上記の考方尔裏付けている.

$$
5 \text { 結論 }
$$

SUS 304 鋼扰上び一部 $21 / 4 \mathrm{Cr}-1 \mathrm{M}$ o 鋼 (水焼入材) について，高温っリープ条件下の表面き裂伝ぱ挙動を 通常の大きいき裂怙よび微小き裂について検討し, 次 の結論を得た。

（1）き裂形状は，ほとんどの場合潘滦半円形で，試 験片表面方向と深さ方向のき裂伝ば速度は注潘等しか 口草.

（2）一定応力下のクリープき裂伝ぱ速度は, 修正 J
積分 $\dot{゙} て ゙$ 整理すると，304鋼（大きいき裂，微小き裂）， $\mathrm{Cr}-\mathrm{Mo}$ 鋼（大きいき裂）いずれの場合も，貫通き裂 の結果と注ぼ一致した。微視的破面はいずれも粒界ク リープ破壤であった。

（3）繰返し応力下の大きいき裂の伝ぱ速度は, 既報 の貫通き裂の場合と同様，低き裂伝ぱ速度域では $\Delta K$ 支配, 高伝ば速度域では方支配で步り, 微視的破面様 相は， $\Delta K$ 支配域ではストライエーション状模様（疲 労破壤)，方支配域ではディンプル（クリープ破壊） が支配的であった。

（4）繰返し応万下の微小き裂の伝ぱは，低伝ぱ速度 域に打いても支配で, 微視的破面様相は乞れ飞るか かわらずストライエーション状模様 (疲学破壊) であ った。これは、き裂が短いため小規模降伏条件が満足 されないことによるものと考克られる。

本研究には大阪大学基礎工学部に和以西筆者らの研 究室の諸氏の協力を得た。 また, 試験に使用した $\mathrm{Cr}-$ Mo 鋼は日立造船技術研究所上田穾彦氏にご提供頂い た、ここに感謝の意を表する。また，本研究には昭和 55 ，56年度文部省科学研究費 (一般研究C) の補助を 得た。付記して謝意を表する。

(炤和57年 6 月27日 第 3 回フラクトグラフィシンポジウムにて講演)

\section{参 考 文 献}

1）小寺沢良一，森 時彦，材料， 26，948 (1977).

2) R. Koterazawa and T. Mori, Trans. ASME, Ser, H, 99, 298 (1977).

3）小寺沢良一，西川義富美，森 洔彦，材料， $27 ， 92$ (1978).

4) 小寺沢良一, 森 時彦, 材料, 27,1178 (1978).

5）小寺沢良一，森 時彦，中井友充，材料， 29， 592 (1980).

6) R. Koterazawa and T. Mori, Proc. Int. Conf., “Engineering Aspects of Creep”, Sheffield, p. 219(1980).

7) 小寺沢良一, 森 時彦, 材料, 29, 1135 (1980).

8）大路清嗣，小倉敬二，久保司郎，日本機械学会論文集， 44, 1831 (1778).

9）大谷隆一，奥野道雄，清水良亮，材料，31，505（1982）。 